Hydrol. Earth Syst. Sci., 17, 4817-4830, 2013

www.hydrol-earth-syst-sci.net/17/4817/2013/

doi:10.5194/hess-17-4817-2013

(c) Author(s) 2013. CC Attribution 3.0 License.

\title{
GRACE water storage estimates for the Middle East and other regions with significant reservoir and lake storage
}

\author{
L. Longuevergne ${ }^{1}$, C. R. Wilson ${ }^{2}$, B. R. Scanlon ${ }^{3}$, and J. F. Crétaux ${ }^{4}$ \\ ${ }^{1}$ CNRS-Géosciences Rennes UMR6118, Université de Rennes 1, Rennes, France \\ ${ }^{2}$ DGS, Jackson School of Geosciences, The University of Texas at Austin, Austin, TX, USA \\ ${ }^{3}$ BEG, Jackson School of Geosciences, The University of Texas at Austin, Austin, TX, USA \\ ${ }^{4}$ CNES/LEGOS, 14, av. Édouard-Belin, 31400 Toulouse, France
}

Correspondence to: L. Longuevergne (laurent.longuevergne@ univ-rennes1.fr)

Received: 9 September 2012 - Published in Hydrol. Earth Syst. Sci. Discuss.: 1 October 2012

Revised: 15 July 2013 - Accepted: 18 October 2013 - Published: 5 December 2013

\begin{abstract}
While GRACE (Gravity Recovery and Climate Experiment) satellites are increasingly being used to monitor total water storage (TWS) changes globally, the impact of spatial distribution of water storage within a basin is generally ignored but may be substantial. In many basins, water is often stored in reservoirs or lakes, flooded areas, small aquifer systems, and other localized regions with areas typically below GRACE resolution $\left(\sim 200000 \mathrm{~km}^{2}\right)$. The objective of this study was to assess the impact of nonuniform water storage distribution on GRACE estimates of TWS changes as basin-wide averages, focusing on surface water reservoirs and using a priori information on reservoir storage from radar altimetry.

Analysis included numerical experiments testing effects of location and areal extent of the localized mass (reservoirs) within a basin on basin-wide average water storage changes, and application to the lower Nile (Lake Nasser) and TigrisEuphrates basins as examples. Numerical experiments show that by assuming uniform mass distribution, GRACE estimates may under- or overestimate basin-wide average water storage by up to a factor of $\sim 2$, depending on reservoir location and areal extent.

Although reservoirs generally cover less than $1 \%$ of the basin area, and their spatial extent may be unresolved by GRACE, reservoir storage may dominate water storage changes in some basins. For example, reservoir storage accounts for $\sim 95 \%$ of seasonal water storage changes in the lower Nile and $10 \%$ in the Tigris-Euphrates. Because reservoirs are used to mitigate droughts and buffer against cli-
\end{abstract}

mate extremes, their influence on interannual timescales can be large.

For example, TWS decline during the 2007-2009 drought in the Tigris-Euphrates basin measured by GRACE was $\sim 93 \mathrm{~km}^{3}$. Actual reservoir storage from satellite altimetry was limited to $27 \mathrm{~km}^{3}$, but their apparent impact on GRACE reached $45 \mathrm{~km}^{3}$, i.e., $50 \%$ of GRACE trend. Therefore, the actual impact of reservoirs would have been greatly underestimated $\left(27 \mathrm{~km}^{3}\right)$ if reservoir storage changes were assumed uniform in the basin. Consequently, estimated groundwater contribution from GRACE would have been largely overestimated in this region if the actual distribution of water was not explicitly taken into account.

Effects of point masses on GRACE estimates are not easily accounted for via simple multiplicative scaling, but in many cases independent information may be available to improve estimates. Accurate estimation of the reservoir contribution is critical, especially when separating estimating groundwater storage changes from GRACE total water storage (TWS) changes. Because the influence of spatially concentrated water storage - and more generally water distribution - is significant, GRACE estimates will be improved by combining independent water mass spatial distribution information with GRACE observations, even when reservoir storage is not the dominant mechanism. In this regard, data from the upcoming Surface Water Ocean Topography (SWOT) satellite mission should be an especially important companion to GRACE-FO (Follow-On) observations. 


\section{Introduction}

Large rivers cross the Middle East and bring life to these dry regions, where throughout human history reservoirs have served to ensure an adequate water supply by storing water in times of surplus and releasing it in times of scarcity (Altinbilek, 2002), providing a buffer to mitigate seasonal and interannual variability in precipitation. Regulation to ensure water supply and control floods may become even more critical in the future with projected increasing intensity of the hydrologic cycle (Easterling et al., 2000). Today half the world's large dams were built exclusively or primarily for irrigation, and an estimated $30-40 \%$ of irrigated lands rely on reservoirs (WCD, 2000). The last century saw a rapid global increase in large-dam building, from $\sim 5000$ through 1950 , mostly in industrialized countries, to $\sim 45000$ by the end of the 20th century (Biswas and Tortajada, 2001) in $\sim 150$ countries. About $50 \%$ of the dams were built mainly for irrigation purposes, mostly in India (World Bank, 1998). Water inflows to reservoirs are mostly controlled by precipitation and water convergence from contributing basins, while outflows are subject to laws and policies serving agricultural, industrial, and urban needs, in addition to physical processes of evaporation and seepage. Most reservoirs are above ground, but below-ground reservoirs in aquifers (groundwater banks) with $\sim 2-3 \mathrm{~km}^{3}$ of water storage have been developed in the Central Valley of California, and are in service elsewhere.

Reservoirs may strongly influence relationships among countries. For example, in the Tigris-Euphrates basin, population growth and increasing reliance on irrigated agriculture have raised water sharing issues between upstream (Turkey) and downstream users (Syria and Iraq) and is causing strong rivalries in this transboundary watershed. Continued development of hydraulic resources in upstream Tigris-Euphrates has also lead to higher sensitivity to droughts and lower water quality downstream, further aggravating the geopolitical environment (Mutin, 2009). While dam building was the path of progress a few decades ago, it may now be a source of deepening water inequality among riparian countries. Because of limited ground-based observation, GRACE satellite data should be valuable for monitoring water storage changes in these basins. Accurate GRACE water storage estimates have importance beyond practical hydrology, given the politics and conflicts associated with drought and transboundary water allocation and management among Turkey, Syria, and Iraq. Recent global modeling studies for this region have suggested a net increase in groundwater storage because of increased recharge from surface water irrigation (Döll et al., 2012). In contrast, GRACE water storage changes for the Tigris-Euphrates basin and western Iran were attributed to large-scale groundwater depletion $\left(77 \mathrm{~km}^{3}\right)$ during a recent drought (2007-2009) (Voss et al., 2013). Although they cover different time periods and spatial scales, fundamental differences between these published estimates underscore the need for accurate assessment of TWS changes and identifi- cation of contributions from different storage components, including a careful assessment of the reservoir storage component.

GRACE satellites (Tapley et al., 2004) are unique in their ability to monitor changes in total water storage ( $\Delta$ TWS), a combination of changes in ice + snow water equivalent storage ( $\triangle$ SWES), surface water storage, often dominated by reservoir storage ( $\triangle$ RESS), soil moisture storage $(\triangle \mathrm{SMS})$ and groundwater storage ( $\triangle$ GWS) (Güntner, 2008; Schmidt et al., 2008). The objective of many GRACE studies is to separately estimate the contribution of groundwater storage changes. This requires disaggregating $\triangle \mathrm{TWS}$ as follows:

$\Delta \mathrm{GWS}=\Delta \mathrm{TWS}-\Delta \mathrm{SWES}-\Delta \mathrm{RESS}-\Delta \mathrm{SMS}$.

Many studies neglect surface water storage changes although this leads to accumulating errors in GWS estimates (e.g., Xavier et al., 2010; Frappart et al., 2011; Frappart et al., 2012; Shamsudduha et al., 2012). One difficulty is that surface water storage changes are often concentrated in small areas, such as lakes, rivers, and flooded areas. Consequently, few land surface models (LSMs) explicitly model surface water routing (Alkama et al., 2010, Vergnes and Decharme, 2012). A related problem is that surface water is often stored within artificial reservoirs ( $\triangle$ RESS) under anthropic control, and is therefore frequently omitted from LSMs.

The spatial resolution of GRACE data is usually given as $\sim 200000 \mathrm{~km}^{2}$, reflecting the spatial resolution of the gravity field estimable from the satellite altitude $(\sim 450 \mathrm{~km})$. However, GRACE is actually sensitive to total mass changes concentrated within a smaller area if the magnitude is sufficient. In agricultural regions, for example, where groundwater systems are exploited in conjunction with surface water (e.g., Scanlon et al., 2012b), a separate estimate of groundwater storage variations requires estimation of the surface water contribution, mostly from reservoirs. As a result, anthropic management of reservoirs and anthropic contributions to the water cycle have recently been incorporated into global modeling studies (Liu and Yang, 2010; Döll et al., 2012; Pokhrel et al., 2012; Wada et al., 2012). Recently, Siebert et al. (2010) developed a database of irrigation, the primary consumer of water resources, separating surface water and groundwater sources of irrigation (Siebert et al., 2010).

Virtually all reservoirs are point masses at the spatial resolution of GRACE. For example, a large reservoir with a typical surface area of $\sim 1000 \mathrm{~km}^{2}$ is about two orders of magnitude less than that of the smallest basin $\left(\sim 200000 \mathrm{~km}^{2}\right)$ that can be typically resolved by GRACE observations. The precision of GRACE observations allows detection of $1 \mathrm{~cm}$ TWS change within a $200000 \mathrm{~km}^{2}$ basin $\left(=2 \mathrm{~km}^{3}\right.$ TWS change). This is comparable in mass (hence detectability) to a $2 \mathrm{~m}$ water level change within a $1000 \mathrm{~km}^{2}$ reservoir. The capability of GRACE to monitor reservoirs was documented in a prelaunch study by Boy and Chao (2002) for the Three Gorges Reservoir and examined subsequently by Wang et al. (2011). Other GRACE studies have examined storage in 
African lakes (Swenson and Wahr, 2009; Becker et al., 2010), and the Aral Sea (Singh et al., 2012), which are larger than artificial reservoirs, but smaller than nominal GRACE resolution. In these studies, GRACE observations were supplemented with satellite radar altimetry observations of water level changes.

While the contributions of reservoirs to water storage changes have been recognized, their quantitative influence has not been clearly included in most previous studies. More precisely, it has not been clear how small scale and/or discontinuous distributions of water sources affect basin-scale average water storage changes typically estimated from GRACE data. For example, Rodell et al. (2009) estimated groundwater depletion in NW India. Because of filtering associated with GRACE processing, water storage changes from GRACE are damped and need to be rescaled to restore basin-scale water storage changes. The study by Rodell et al. (2009) recognized water storage changes at varying spatial scales by applying different multiplicative factors for rescaling seasonal variations and trends in GRACE processing. Seasonal variations were attributed to soil moisture, distributed over an area much larger than that of the aquifer, while trends were attributed to groundwater storage changes within the basin. The same conclusions were explicitly drawn by Feng et al. (2013) when studying the groundwater contribution to TWS changes in the North China Plain, distributing a priori information on groundwater mass to accurately rescale GRACE data. Recently, Scanlon et al. (2012a) noted that the effective multiplicative (scaling) factor required to correct for spatial distribution may vary by $\sim 15 \%$ among storage components due to varying spatial distribution. For example, snow is usually concentrated within mountains on a basin perimeter, while soil moisture tends to be more evenly distributed over a basin. The fundamental problem is that water storage variations in spatially-limited regions are to be estimated from spectrally-limited (GRACE) data (Simons et al., 2006).

The objective of this study was to evaluate the contribution of nonuniform water storage distribution to GRACE TWS changes as basin-wide averages. Point masses are used to represent the distribution of typical reservoirs in simple synthetic numerical modeling experiments. Then, examples from basins with large reservoir components are presented, which combine independent satellite radar altimetry observations of reservoir storage with GRACE data. The examples demonstrate the importance of combining spatial distribution information when disaggregating TWS changes into reservoir, soil moisture, and groundwater storage changes.

\section{Methods and data sets}

\subsection{Synthetic numerical experiment}

The influence of spatially concentrated water storage changes on GRACE is illustrated using two simple synthetic numerical experiments. Results apply to any spatially concentrated water storage component (glaciers, rivers, reservoirs, small-scale groundwater systems) estimated from GRACE observations, whether in spherical harmonic (SH), gridded (Landerer and Swenson, 2012) or "mascon" (e.g., Tiwari et al., 2009; Rowland et al., 2010) formats, given that spatial resolution is constrained by potential field physics to be comparable to GRACE satellites' altitude of $\sim 400 \mathrm{~km}$. In these experiments, a point mass representing a $1 \mathrm{~km}^{3}$ water storage reservoir within a simple circular basin is used to compute the corresponding change in GRACE estimate of water storage for the basin. In practice, the computations are performed using a $1 / 8$ th degree grid $(\sim 12 \times 12 \mathrm{~km})$. In the first experiment, the location of the point mass is varied relative to the basin center. In the second experiment, the mass is fixed at the basin center, but its spatial extent increases from a concentrated point up to a uniform distribution over the entire basin.

Spherical harmonic representations of surface mass change were used (Wahr et al., 1998), limiting degree and order to 50 (to simulate data from GRGS), and to 60 (to simulate data from CSR, including a Gaussian $300 \mathrm{~km}$ filter). A hard truncation (no filtering) at degree 50 does not exactly duplicate stabilized GRGS solutions at higher degrees (Lemoine et al., 2007). SH expansions of mass change over circular basins of varying size were evaluated, and apparent basin-wide average mass changes were calculated given knowledge of the spatially concentrated true mass within the basin. Apparent basin storage (ABS), in units of water layer thickness, equals the SH expansion of mass (water volume) integrated over the entire basin, divided by basin area. In other words, ABS describes how GRACE captures the impact of point masses prior to any bias/leakage correction. True basin storage (TBS) equals the actual mass located within the basin divided by basin area. For example, in the first experiment, a constant reservoir mass of $1 \mathrm{~km}^{3}$ was given varying locations with a basin area of 0.4 million $\mathrm{km}^{2}$ $\left(\mathrm{M} \mathrm{km}^{2}\right)$ resulting in a TBS of $2.5 \mathrm{~mm}$, while ABS is larger and reaches $3.1 \mathrm{~mm}$ when the mass is at the center.

\subsection{Reservoir data}

In some regions of the world, such as in the US, reservoir storage is monitored and data are publicly available. More commonly, such data are difficult to obtain. However, satellite radar altimetry estimates of reservoir water levels and/or volume changes are available for many large reservoirs. Several missions have been launched since the early 1990s: ERS1 (1991-1996), T/P (1992-2005), ERS-2 (1995-2002), GFO 
(2000-2008), JASON-1 (2001), JASON-2 (2008) and ENVISAT (2002-2012). The combined global altimetry historical data set now covers approximately two decades and will be continuously updated in the coming decade. Merging altimetry data from several altimetry missions also increases the spatiotemporal resolution of remotely-sensed hydrological variables.

We used lake and reservoir level/volume variations obtained from the Hydroweb database (Crétaux et al., 2005; 2011) for regions shown in Table 1 . Time series of water stage, computed from satellite altimetry for 165 natural lakes and artificial reservoirs, are available on http://www.legos. obs-mip.fr/en/soa/hydrologie/hydroweb/. Estimates incorporate specific biases of each satellite (Crétaux et al., 2009). The accuracy of radar altimetry over lakes is $2-3 \mathrm{~cm}$ for large lakes, and up to $70-80 \mathrm{~cm}$ for small and narrow lakes. Lake areas and volumes are also provided in Hydroweb for a selection of 30 lakes worldwide. Information on lake/reservoir area is required for systems with only water level data to calculate water volume changes. Satellite remote sensing optical imagery (mainly Landsat satellites, $30 \mathrm{~m}$ resolution) has been used to detect the presence of water on Earth and estimate lake surface area corresponding to different water levels. A water area-level relationship is therefore derived from integrating satellite radar altimetry and imagery to calculate lake area and water volume variations over time. For cases where lake volumes are unavailable, a constant lake surface area is assumed.

\subsection{Land surface models}

To disaggregate GRACE TWS into different components and to compare with reservoir storage data, we examine water storage estimates from different LSMs, which mainly model changes in soil moisture storage $(\triangle \mathrm{SMS})$ and snow storage equivalent storage ( $\triangle$ SWES) due to natural physical processes. Water storage changes in managed reservoirs are generally not included in LSMs because regulation rules are not well known. However, one LSM, WGHM (WaterGAP Global Hydrology Model) incorporates these variations in some basins (Döll et al., 2003; Hunger and Döll, 2008). A version of WGHM has been calibrated jointly with GRACE and river discharge data (Werth and Güntner, 2010), but the version used in this study is independent of GRACE data. Water storage estimates are also obtained from another widely used LSM, GLDAS (Global Land Data Assimilation System) (Rodell et al., 2004), which omits reservoir water storage changes. GLDAS output includes four different LSMs, CLM, MOSAIC, NOAH and VIC. In the following, GLDAS $\triangle$ SMS is computed as the mean of SMS variations among CLM, MOSAIC, NOAH and VIC, and changes in SWES are computed similarly. The relative importance of RESS changes on the water cycle can be evaluated by comparing GLDAS results with WGHM (which includes reservoirs). Results are compared with GRACE by integrating
LSM grid values over basins available at $0.5^{\circ}$ resolution (Oki and Sud, 1998)

\subsection{GRACE data}

Two different GRACE products were used in this study. The first is based upon monthly Release 04 spherical harmonic (SH) data from CSR (Center for Space Research, Univ. of Texas at Austin, US), truncated at degree and order 60 (Bettadpur, 2007), including a destriping filter (Swenson and Wahr, 2006) and additional $300 \mathrm{~km}$ Gaussian smoothing. The second uses 10 day RL02 data from GRGS (Groupe de Recherche en Géodésie Spatiale), stabilized and truncated at degree 50 (Lemoine et al., 2007; Bruinsma et al., 2010). No additional filtering is required for GRGS solutions. CSR and GRGS solutions use the same GRACE range-rate data and similar geophysical background models, but employ independent processing strategies. They have been selected because CSR solutions are among the least constrained solutions, while GRGS is considered one of the most constrained. In each example, basin-scale water storage changes and associated errors were calculated following procedures outlined by Longuevergne et al. (2010). The GRACE SH expansion of apparent mass change was integrated over the basin, and then bias and leakage corrections were computed assuming GLDAS-NOAH correctly represents water mass variations and distribution both within and outside the basin. Bias and leakage corrections were determined separately using an additive hypothesis, then added to the GRACE apparent mass change. For information purposes, a multiplicative factor $\mathrm{k}$ was also computed by applying the same processing as GRACE to GLDAS-NOAH (truncation and filtering), then comparing processed values with the original model.

Because GLDAS excludes reservoir storage, bias and leakage corrections are likely less accurate when reservoir storage is a major component of the water balance. After bias/leakage corrections, and independently of the method used, GRACE may describe correctly SMS and SWES, but other components are not properly constrained. If an additive correction method is considered, RESS and GWS will remain with the "filtered" signature and bias/leakage would have been corrected for effects of SMS and SWES. In the case of a multiplicative method, the multiplicative factor would not take into account the specific mass distribution of reservoirs, and again, RESS and GWS will not be properly corrected. In this work, we use an additive method to correct for bias/leakage, but the multiplicative approach will also be addressed.

\subsection{Application to regions with significant reservoir and lake storage}

Results from the numerical experiments and other data are used to interpret GRACE water storage estimates of changes within two basins in arid/semi-arid Middle East regions: the 
Table 1. Lake and reservoir data summary. Variability is computed as the standard deviation of lake storage variations over the whole time series. Asterisks refer to reservoirs and lakes that have volume data in the Hydroweb database; for other lakes, we assume constant area.

\begin{tabular}{llll}
\hline Region & Lake name & Area $\left[\mathrm{km}^{2}\right]$ & Variability $\left[\mathrm{km}^{3}\right]$ \\
\hline $\begin{array}{l}\text { Lower Nile } \\
\left(410000 \mathrm{~km}^{2}\right)\end{array}$ & Nasser & $6200 \mathrm{~km}^{2}$ & $16 \mathrm{~km}^{3}$ \\
\hline & & & \\
Tigris-Euphrates & & & \\
$\left(790000 \mathrm{~km}^{2}\right)$ & TOTAL & $15300 \mathrm{~km}^{2}$ & $24 \mathrm{~km}^{3}$ \\
& Asad & 447 & 0.30 \\
& Atatürk & 707 & 1.6 \\
& Daryace* (outside) & 5200 & 3.7 \\
& Mossoul & 285 & 1.8 \\
& Qadisiyah* & 415 & 3.3 \\
& Razazah & 1501 & 1.9 \\
& Saksak* & 458 & 1.7 \\
& Tharthar & 2500 & 8.3 \\
& Van & 3755 & 1.0 \\
\hline
\end{tabular}

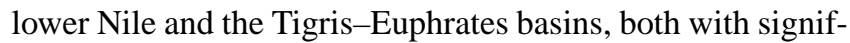

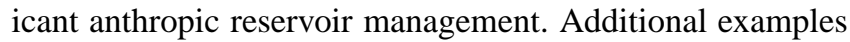

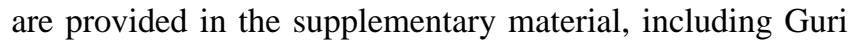

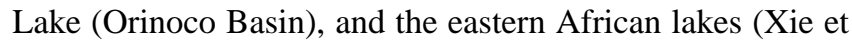

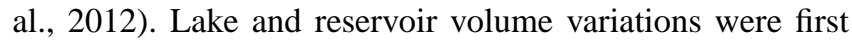

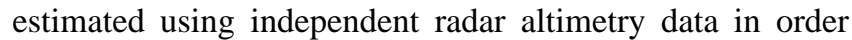

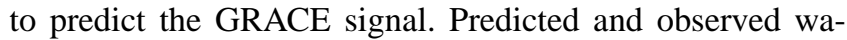

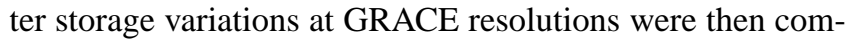

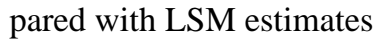

\subsubsection{Lower Nile basin}

Lake Nasser $\left(6216 \mathrm{~km}^{2}\right.$ area, $\sim 500 \mathrm{~km}$ long) is located in the lower Nile basin at the border between Egypt and Sudan (Fig. 3). The lake was filled in the 1960s to 1970s with the construction of the Aswan High Dam upstream of the old Aswan Dam. The total capacity of the reservoir is $162 \mathrm{~km}^{3}$ at the level $182 \mathrm{~m}$ amsl (Sadek et al., 1997). Lake levels may vary by up to $7 \mathrm{~m}\left(\sim 43 \mathrm{~km}^{3}\right)$ between summer and winter, with evaporation accounting for $2.4 \mathrm{~m}$ ( $15 \%$ of river inflow) and seepage to nearby aquifers accounting for $0.23 \mathrm{~m}(1.2 \%$ of river inflow), see Aly et al. (1993). The lower Nile basin is also important because the region evaluated in this study covers $\sim 30 \%$ of the Nubian Aquifer System (NAS). There is interest in applying GRACE to evaluate groundwater storage changes in the NAS. The NAS extends over more than $2 \mathrm{M} \mathrm{km}^{-2}$ and is one of the largest groundwater systems in the world, shared by Egypt, Lybia, Sudan and Chad (Sultan et al., 1997; Gossel et al., 2008). As annual rainfall is below $15 \mathrm{~mm} \mathrm{yr}^{-1}$, NAS is the only major freshwater resource in the eastern Sahara besides the River Nile. In this arid area, recharge from rainfall is limited to a couple of $\mathrm{mm}$ a year. Water stored within this aquifer is mostly fossil nonrenewable groundwater accumulated during the Quaternary (Sultan et al., 1997). Groundwater extraction has been rapidly increasing, and the NAS is now being mined in several areas, mainly in oases spread over Egypt and Libya, west of the Nile valley, with pumping rates reaching 10 times natural discharge (Gossel et al., 2008).

\subsubsection{Tigris-Euphrates basin}

The Tigris-Euphrates (TE) basin has seen anthropic management for over six millennia. The regional climate is dominated by winter precipitation, with snow in surrounding mountain ranges (Jones et al., 2008). Therefore, summer crop production relies heavily on irrigation. For example, Mesopotamia (from the Greek "land between two rivers"), as the cradle of modern civilization, was built upon the wealth of irrigated agriculture and remains one of the most engineered basins in the world. Irrigation greatly expanded at the beginning of the 20th century. Both rivers originate in Turkey and construction of several dams in Turkey and Syria has greatly reduced flow into downstream Iraq. Jones et al. (2008) showed large streamflow reduction in the TE basin related to dam impoundment and operations in the 1989-1998 period, compared to predevelopment (19651973), reaching 26 to $48 \%$ at annual timescales. Streamflow decreased by $75 \%$ in January 1990 when Turkey began to fill the Atatürk reservoir, leading to crop loss of $15 \%$ (Mutin, 2009). Beyond dam storage, water loss by evapotranspiration (lake surface, crop irrigation) and seepage also decreases streamflow and increases sensitivity of downstream reservoirs to droughts.

\section{Results of synthetic numerical experiment}

The overall impact of a point mass on GRACE basin-wide average water storage changes includes several different 
effects: mass location and area, basin area, and details of GRACE processing. In the first experiment (Figs. 2, S1), the location of a point mass representing $1 \mathrm{~km}^{3}$ of water (assigned to a $1 / 8$ th degree cell, or $140 \mathrm{~km}^{2}$ ) was varied relative to the basin center for basins of various areas (Figs. 2, S1). Three main results are evident:

1. The position of a point mass strongly affects the impact of a point mass on GRACE mass changes. Apparent basin storage (that is, GRACE TWS estimates prior to bias/leakage correction) exceeds TBS (actual mass located within the basin divided by basin area) when the point mass is concentrated in the basin center and diminishes rapidly as the mass moves offcenter due to leakage to regions outside the basin. For example, a 0.4 million $(\mathrm{M}) \mathrm{km}^{2}$ basin has TBS = $2.5 \mathrm{~mm}\left(1 \mathrm{~km}^{3} / 0.4 \mathrm{M} \mathrm{km}^{-2}\right)$, but ABS is $24 \%$ larger $(3.1 \mathrm{~mm}$ ) when the point mass is at the center (Fig. 2a). When located near the edge, ABS is $50 \%$ lower $(1.2 \mathrm{~mm})$ than TBS. ABS diminishes quickly as the mass moves off-center due to leakage to regions outside the basin. The impact of a point mass located outside the basin may be important, especially for small basins (area $<300000 \mathrm{~km}^{2}$ ).

2. Basin area modulates the magnitude of the point mass effect (Fig. 2b). ABS is always less than TBS for basin area below $0.3 \mathrm{M} \mathrm{km}^{-2}$. For example, a $0.2 \mathrm{M} \mathrm{km}^{2}$ basin with $\mathrm{TBS}=5 \mathrm{~mm}$, while $\mathrm{ABS}=4.1 \mathrm{~mm}$ when located at the basin center and $2.5 \mathrm{~mm}$ at the basin edge. Conversely, ABS may be larger than TBS for larger basins, causing overestimation of TWS. When the basin is small (area $<0.3 \mathrm{M} \mathrm{km}^{-2}$ ), point masses outside the basin also yield a similar ABS as point masses inside the basin. Thus, knowledge of storage changes close to a basin edge are required to properly estimate leakage.

3. ABS is strongly affected by processing methods, especially filtering (Fig. $2 \mathrm{~b}$ and c) smoothing. Including up to SH degree 60, with additional $300 \mathrm{~km}$ Gaussian smoother (similar to processing of CSR data), yields ABS that is biased because smoothing spreads the signal over a large area. Thus, ABS is diminished relative to the degree 50 case (similar to processing of GRGS data). Improvement of spatial resolution (reduced spatial filtering) makes GRACE basin-wide averages more sensitive to the impact of point masses.

In the second experiment (Figs. 2, S2), the mass is centered within the basin but its radius is varied from a point (1/8th degree) up to the basin radius. The results are described by relative ABS, the ratio of ABS divided by its value when mass radius equals the basin radius (equivalent to assuming a uniform distribution for storage). More concentrated masses increase the relative ABS as much as $60 \%$

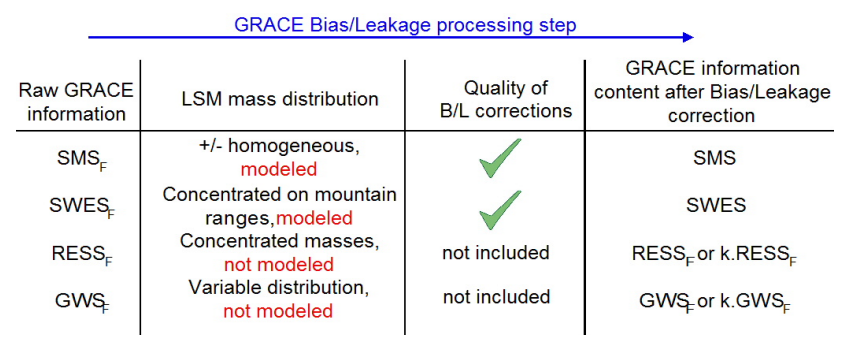

Fig. 1. Schematic showing the impact of modeled and unmodeled storage compartments in LSMs on the Bias/Leakage correction, considering a perfect LSM limited to SMS and SWES. Subscript F represents spatial filtering, i.e., truncation to degree 50 (equivalent to GRGS processing) and degree 60 (equivalent to CSR processing), and $300 \mathrm{~km}$ Gaussian filtering (CSR). Two bias/leakage correction methods may be used: a multiplicative method, applying a factor $\mathrm{k}$ based on mass distribution from LSM, or an additive hypothesis. In both cases, as storage compartments do not have the same mass distribution, bias/leakage corrections are only valid for modeled storage compartments in LSMs, which generally do not include RESS and GWS. Rescaled GRACE data may correctly describe SMS and SWES, other components, however, are not properly constrained.

(multiplicative factor of 1.6) because leakage to regions outside the basin is diminished with greater concentration. Hardtruncation negative sidelobes in the degree 50 case reduce relative ABS for larger basins.

These two experiments can be used to interpret GRACE estimates of TWS changes for basins with spatially irregular water storage distribution. A first point is that the impact of concentrated masses on GRACE (ABS) is rarely equal to their true value (TBS) and may be smaller or larger, depending upon the position of the mass and its areal extent with respect to the basin area. Masses outside a basin may contribute significantly by leakage into the basin. Second, the signal produced by a concentrated mass tends to increase with concentration. If a point mass is located near the center of the basin and its distribution is incorrectly assumed to be uniform, GRACE estimates may overestimate the actual mass storage by more than $50 \%$. When no smoothing is applied, the impact of a point mass will be close to true storage when the reservoir is located half way between the center and edge of the basin and has a small area. When smoothing is applied, ABS is always less than TBS. As a conclusion, considering actual mass distribution within a basin is necessary when processing GRACE data to accurately quantify basinwide water storage changes from GRACE.

\section{Application to specific basins}

\subsection{Lower Nile basin and Lake Nasser}

The impact of anthropic water management is evident from differences between GLDAS $\Delta$ SMS (which does not include Lake Nasser storage changes) and WGHM (incorporating 


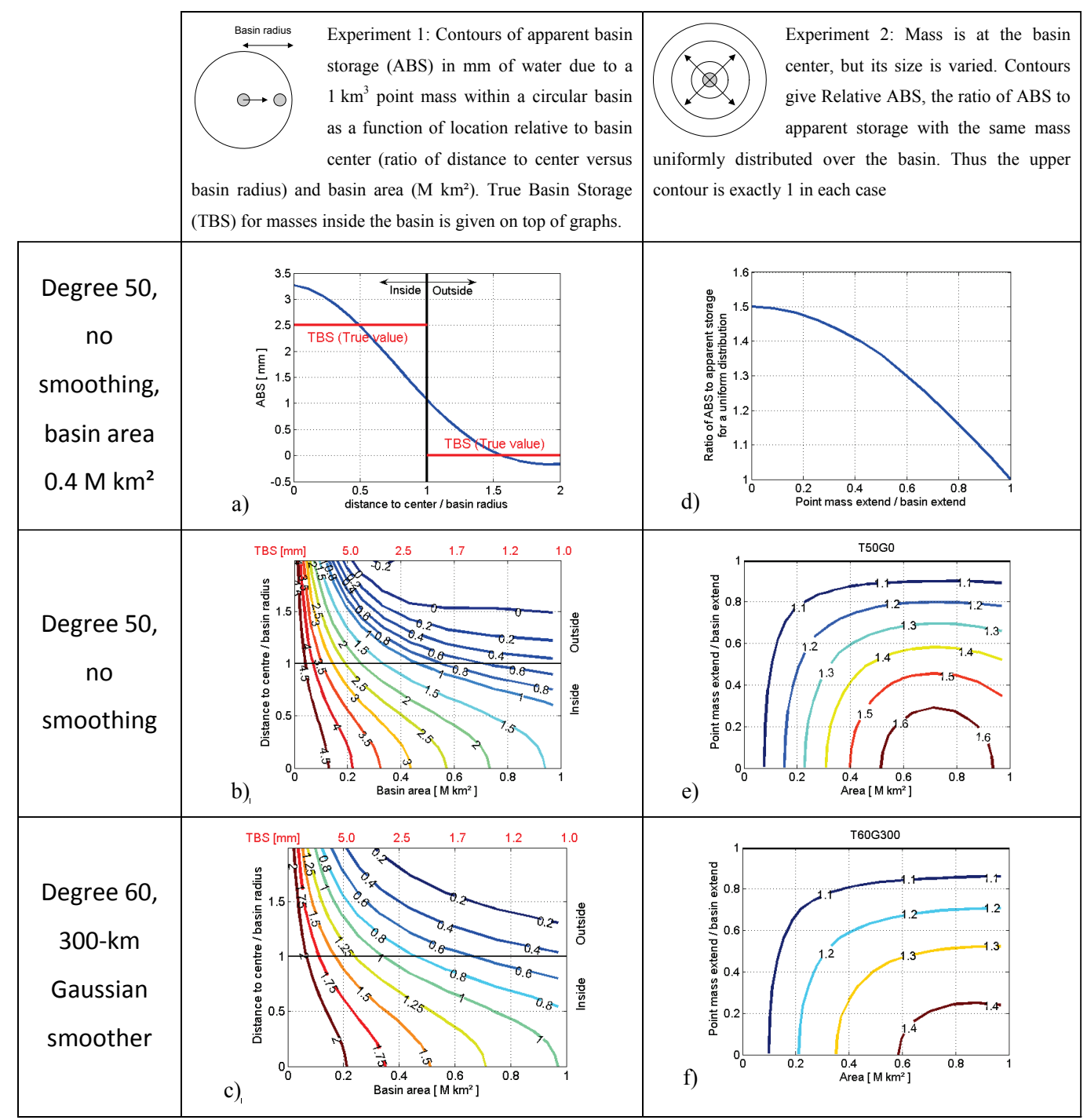

Fig. 2. Numerical experiment of the impact of a $1 \mathrm{~km}^{3}$ point mass to basin-wide estimates of water storage. In terms of GRACE processing, degree 50 no smoothing generally corresponds to processing applied to GRGS data and degree 60 plus 300 km Gaussian smoothing generally corresponds to processing applied to CSR data. (a) Shows a contour of apparent basin storage (ABS) with varying location of the point mass from the basin center to outside the basin. True basin storage (TBS) is $2.5 \mathrm{~mm}\left(1 \mathrm{~km}^{3} 0.4 \mathrm{M} \mathrm{km}^{-2}\right)$. (b) Shows contours of ABS in mm for varying basin areas (horizontal axis) and increasing distance of the mass from the basin center (vertical axis). (d), (e) and (f) Show contours of ABS divided by the same impact (apparent storage) when the mass is distributed uniformly for varying basin areas (horizontal axis) and decreasing concentration (vertical axis). Refer to supplementary information S1 and S2 for more case studies and additional figures.

Lake Nasser regulation rules) over the lower Nile basin (Fig. 3). The difference is $\sim 40 \mathrm{~mm}\left(\sim 16 \mathrm{~km}^{3}\right)$ for seasonal variations. GRACE estimates clearly capture changes in Lake Nasser, though some differences in phase are evident during September/October of 2007 and 2008. As Lake Nasser is at the edge of the lower Nile basin, its impact on GRACE can be understood using the numerical experiment results. Lake Nasser is $1.5 \%$ of the lower Nile basin area; therefore, $\mathrm{ABS}$ would be $\sim 1 / 2$ the lake volume variations distributed over the basin (TBS). If the lake mass is assumed uniformly distributed over the lower Nile basin, then its im- pact on GRACE (170 $\mathrm{mm}$ between minimum and maximum, $69 \mathrm{~km}^{3}$ ) is twice the actual impact, considering the spatial distribution of concentrated mass variations $\left(80 \mathrm{~mm}, 32 \mathrm{~km}^{3}\right.$, similar to what GRACE captures), as expected from Experiment 1 . A consequence is that long-term variations in the lake contribution to water storage changes would be overestimated if uniform distribution was assumed. While the area of Lake Nasser constitutes only $1.5 \%$ of the lower Nile basin, it accounts for $\sim 95 \%$ of the water storage changes as annual rainfall is below $15 \mathrm{~mm}_{\text {year }}{ }^{-1}$. 

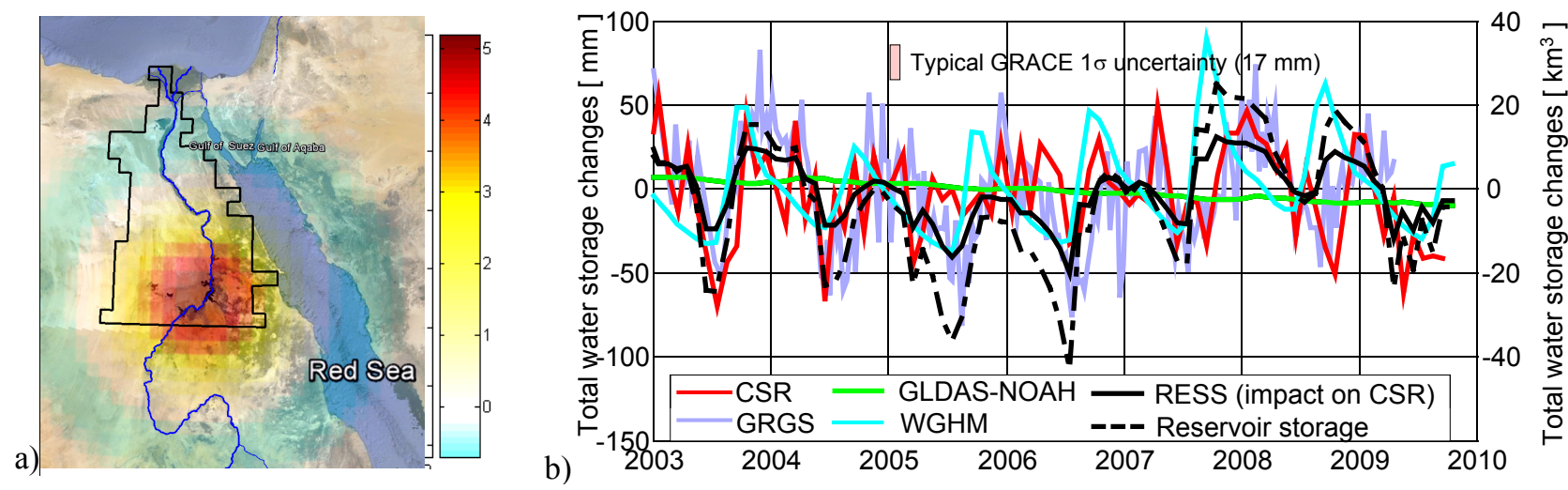

Fig. 3. (a) Google Earth map of the lower Nile basin $\left(410000 \mathrm{~km}^{2}\right)$; outlines are indicated in black. Superimposed is the apparent water storage change for a $1 \mathrm{~km}^{3}$ mass change (equivalent to a $160 \mathrm{~mm}$ lake level variation) distributed over Lake Nasser after hard SH truncation at degree 50 (similar to GRGS). Note the negative sidelobes associated with hard truncation. The outline of the area of interest is artificially set at the Egypt-Sudan border to focus on the very dry area and to compute the impact of a single point mass located at the border of the area of interest. (b) The colored lines show Nile basin total water storage (TWS) change anomalies from GRACE CSR and GRGS, GLDASSMS, WGHM (which includes Lake Nasser). Black lines show predicted impact of Lake Nasser on CSR ( $\triangle$ RESS - solid line, ABS) and the simple reservoir volume from altimetry uniformly distributed over the basin (dashed line, TBS). Lake Nasser accounts for $95 \%$ of the mass variability within the basin.

Estimated impact of Lake Nasser on GRACE relies on the hypothesis that the Lake Nasser area is considered as constant. Abileah and Vignudelli (2011) compared Landsatderived lake area and noted a $0.4 \mathrm{~km}^{2}$ lake area variation per meter of water level variation. Therefore, lake volume variations using satellite altimetry are underestimated. The main conclusions are however unchanged, namely that it is important to take into account lake area and position within the basin of interest to accurately compute impact on GRACE estimates.

Application of GRACE data in this region to estimate groundwater storage variations is subject to careful consideration of three main points: (1) the impact of surface water from reservoirs, and also long-term storage variations from temporary lakes located further west in the Tushka depression. These lakes are created by unusual water rise in Lake Nasser induced by high precipitation in the Ethiopian Highlands (Abdelsalam et al., 2008). During the last wet period, these lakes covered an area of $1586 \mathrm{~km}^{2}$. Recharge of the $\mathrm{Nu}-$ bian aquifer by these intermittent lakes is insignificant as they are underlain by impermeable shale and chalk formations. (2) The complex nature of the aquifer system also needs to be considered. NAS is confined over most of the northern half of the aquifer, where most pumping stations are located, but also overlain by the unconfined post-Nubian aquifer system. (3) Low GRACE signal amplitude in this region (note high noise amplitude on Fig. 3b) may also be affected by potential leakage from high amplitude water storage variations farther south in the recharge area (Abdelsalam et al., 2008).

\subsection{Tigris-Euphrates basin}

In the TE basin, the nine largest reservoirs have been taken into account (Table 1; Fig. 4a). As suggested by Experiment 1 , reservoirs outside the TE basin are also included to estimate spatial leakage into the TE basin. Lake Tharthar $\left(2500 \mathrm{~km}^{2}\right)$ constitutes $\sim 35 \%$ of the overall mass variability in the basin, with $\sim 7 \mathrm{~m}$ water level decrease $\left(\sim 17 \mathrm{~km}^{3}\right)$ during the recent three year drought between October 2007 to September 2009. As it is located near the center of the basin (Experiment 1) and has a reduced small area (Experiment 2), it is expected to contribute significantly to the GRACE signal. Predicted impact of reservoir storage to CSR (seasonal variations $\sim 6.8 \mathrm{~mm}, 5.4 \mathrm{~km}^{3}$ ) is nearly twice as large as the sum of reservoir storage variations uniformly distributed over the basin ( $3.9 \mathrm{~mm}$ or $3 \mathrm{~km}^{3}$; see Table 2, Fig. $\left.4 \mathrm{~d}\right)$. In addition, the effect for GRGS is larger than for CSR (not shown), giving GRGS larger seasonal maxima and minima on time series (Fig. 4d).

While artificial reservoirs cover only $0.8 \%$ of the $790000 \mathrm{~km}^{2}$ basin, they account for about $10 \%$ of seasonal water storage variations on GRACE $\left(\sim 60 \mathrm{~mm}, 47 \mathrm{~km}^{3}\right.$; Table 2, Fig. 4). As a result the cycle of water storage variations differs from natural storage variations simulated by GLDAS snow and soil moisture changes $\left(\sim 43 \mathrm{~mm}, 34 \mathrm{~km}^{3}\right)-$ which does not include reservoirs causing a 15 day phase shift in the seasonal signal (Tables 2 and S2). Indeed, the role of irrigation is to store water from times of excess for use during dry periods, which shifts the phase towards the summer season. Summing predicted reservoir storage with GLDAS shows improved agreement with GRACE in both amplitude 
Table 2. Comparison between GRACE changes in soil moisture ( $\triangle \mathrm{SMS}$ ) and snow water equivalent ( $\triangle \mathrm{SWES})$ from GLDAS (mean of CLM, MOSAIC, NOAH, VIC models) and reservoir storage changes ( $\triangle$ RESS) for Tigris-Euphrates basin. Please refer to supplementary material Table $\mathrm{S} 1$ for comparison with more LSM models. Uncertainty is given as the impact of variability of $\Delta \mathrm{SMS}+\Delta \mathrm{SWES}$ among LSMs in GLDAS. Uncertainty of $\triangle$ RESS is not taken into account

\begin{tabular}{|c|c|c|c|c|c|}
\hline & $\begin{array}{r}\text { GRACE } \\
\text { CSR }\end{array}$ & $\begin{array}{r}\Delta \text { SMS }+ \\
\Delta \text { SWE from } \\
\text { GLDAS }\end{array}$ & $\begin{array}{r}\text { Computed } \triangle \text { RESS } \\
\text { contribution to } \\
\text { GRACE }(\mathrm{ABS})\end{array}$ & $\begin{array}{r}\triangle \text { RESS from } \\
\text { altimetry } \\
\text { (TBS) }\end{array}$ & $\begin{array}{r}\Delta \text { SMS + } \\
\Delta \text { SWE + } \\
\Delta \text { RESS }\end{array}$ \\
\hline Seasonal amplitude $[\mathrm{mm}]$ & $60 \pm 7$ & $43 \pm 5$ & $6.8(10 \%)$ & $3.92(6 \%)$ & $45.1 \pm 5$ \\
\hline Phase (seasonal) [ days ] & Reference & -22 & +15 & & -12 \\
\hline Correlation & Reference & 0.89 & & & 0.95 \\
\hline RMS with GRACE [ mm ] & Reference & 31 & & & 23 \\
\hline Trend $(2002 / 10-2009 / 09)$ [ mm/year ] & $-11 \pm 0.8$ & $-5.8 \pm 2.3$ & $-4.2(40 \%)$ & $-2.25(20 \%)$ & $-9.9 \pm 2.3$ \\
\hline Trend $(2002 / 10-2009 / 09)\left[\mathrm{km}^{3} /\right.$ year $]$ & $-8.6 \pm 0.6$ & $-4.6 \pm 1.8$ & $-3.3(40 \%)$ & $-1.75(20 \%)$ & $-7.8 \pm 1.8$ \\
\hline Trend (2006/10-2009/09) [ mm/year ] & $-39 \pm 4$ & $-16 \pm 6.0$ & $-19(49 \%)$ & $-11(28 \%)$ & $-34 \pm 6.0$ \\
\hline Trend (2006/10-2009/09) [ $\mathrm{km}^{3} /$ year $]$ & $-31 \pm 3$ & $-12 \pm 4.8$ & $-15(49 \%)$ & $-9.1(28 \%)$ & $-27 \pm 4.8$ \\
\hline
\end{tabular}

and phase; RMS differences are also reduced by $25 \%$ (Tables 2 and $\mathrm{S} 2$ ).

The improved agreement with GRACE TWS obtained by addition of reservoir storage to GLDAS is likely greater for interannual variations (Fig. 4, Tables 2 and S2) because reservoir management tends to become more important at longer timescales to mitigate drought. Reservoir depletion was estimated $\sim 27 \mathrm{~km}^{3}$ from satellite altimetry. Their impact on GRACE, however, reaches nearly twice this amount $\left(\sim 45 \mathrm{~km}^{3}\right)$ after taking into account the distribution of reservoirs, as expected after having studied the seasonal variations.

The latter evaluation considers an additive method to correct for bias leakage. The computation of a multiplicative factor on this region leads to similar results. When considering GLDAS-NOAH $\triangle \mathrm{SMS}+\Delta \mathrm{SWES}$ as an a priori for water distribution, the multiplicative factor for this region leads to a factor 1.10 for CSR and 1.02 for GRGS. When adding reservoir position and mass changes to the gridded GLDAS$\mathrm{NOAH}$, the multiplicative factor becomes $1.46(+30 \%)$ for CSR and $1.13(+10 \%)$ for GRGS. As a consequence the impact of reservoirs on GRACE will be underestimated by $30 \%$ using CSR when considering the simple reservoir volume changes distributed over the basin. It is clear that the accuracy of multiplicative factor to correct for bias/leakage is limited by the distribution of modeled storage components in LSMs, and each storage compartment would require a specific multiplicative factor to be representative.

Declines in TWS during the three year drought (October 2006 through September 2009) were $93 \mathrm{~km}^{3}$ (CSR) and $91 \mathrm{~km}^{3}$ (GRGS). Therefore, reservoir storage (ABS $45 \mathrm{~km}^{3}$ ) appears to explain $\sim 50 \%$ of trend in water storage changes on GRACE estimates over the drought, while the actual storage contribution (TBS) is limited to $30 \%$ at the basin scale (Table 2). Trends in SWE and SMS from LSMs was $36 \mathrm{~km}^{3}$, ranging from $17 \mathrm{~km}^{3}$ (CLM) to $50 \mathrm{~km}^{3}$ (MOSAIC). Large uncertainty in LSM values, however, makes estimation of the groundwater contribution unreliable. That is, $\Delta \mathrm{SMS}+\Delta \mathrm{SWES}$ from GLDAS in combination with the im- pact of reservoir storage explain most of the GRACE signal, at both seasonal and interannual timescales. Ignoring spatial distribution and areal extent of reservoirs would resulted in estimated GWS declines of $\sim 15 \mathrm{~km}^{3}$ (MOSAIC) to $\sim 45 \mathrm{~km}^{3}$ (CLM) during the $3 \mathrm{yr}$ drought. Long-term groundwater changes appear limited, or possibly related to surface water infiltration. The estimation of groundwater depletion is supported by the sources of irrigation water (Siebert et al., 2010). Indeed, while $\sim 18 \mathrm{~km}^{2}$ area is equipped for irrigation within the basin, only an estimated $20 \%$ of the water is derived from groundwater based on analysis of data from about the year 2000. Recent modeling studies also indicate that return flow from irrigation with surface water replenishes groundwater in this region (Döll et al., 2012). These results differ from those of Voss et al. (2013) and the cause may be related in part to their lack of consideration of reservoir location and area on GRACE water storage estimates and also to differences in basin areas.

The estimated impact of reservoirs on GRACE along with SMS and SWES changes explains much of the apparent mass variability; however, several sources of error should be highlighted. First, SWES is a critical component in surrounding mountains and GLDAS does not seem to accurately estimate these storage variations. Second, not all surface water bodies have been taken into account in this analysis. For example, surface mass variations from the Mesopotamian marshes in southern Iraq are not included here yet their size increased from 750 to $4000 \mathrm{~km}^{2}$ between 2002 and 2005 (Jones et al., 2008), which may account for unmodeled interannual variations (Fig. 3d). Finally, lake volume variations were computed from water level using a constant area for 6 out of the 9 lakes. Both errors would lead to overestimation of longterm depletion in water storage from surface water, but do not change the main conclusions.

Total water storage depletion in this region may be related to the following factors. The first is impoundment and operation of upstream dams, accumulating available water (Jones et al., 2008; Jongerden, 2010). The second is climatic in origin, a drought related to lower than normal rainfall and 

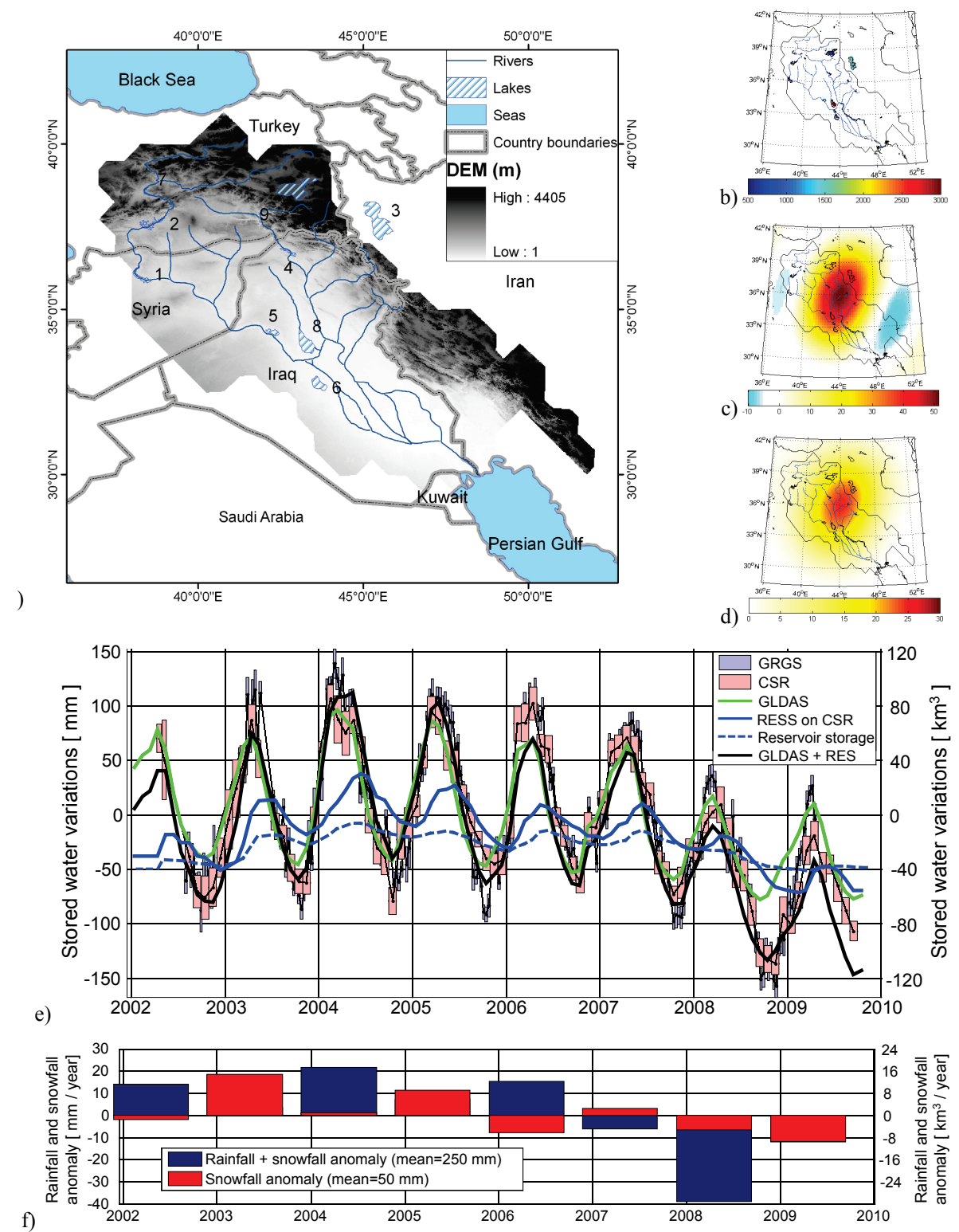

Fig. 4. (a) DEM and river network of the Tigris-Euphrates basin and location of the modeled lakes and reservoirs. (b) Reservoir distribution and standard deviation of lake level variations in $\mathrm{mm}$ for each of the nine Tigris-Euphrates reservoirs and lakes; (c) spatial distribution of reservoir impact on GRACE after hard truncation at degree 50 (similar to GRGS processing); (d) same as (c) but after truncation at degree 60 and $300 \mathrm{~km}$ Gaussian smoothing (similar to CSR processing) (e) Water storage variations for the Tigris-Euphrates basin from GRACE GRGS and CSR, GLDAS SMS, predicted reservoir storage (RESS) impact on CSR and simple sum of reservoir storage changes distributed over the basin. (f) Rainfall and snowfall anomaly over the Tigris-Euphrates basin.

snowfall in the upstream mountains $\left(\sim 60 \mathrm{~mm}\right.$ or $47.5 \mathrm{~km}^{3}$ from 2006-2009 with respect to the $250 \mathrm{~mm}$ annual mean; Fig. 4f). Half of the total depletion in GRACE is linked to soil moisture over the entire region, the other half mainly to depleting Iraqi reservoirs (Fig. 4b). Reservoirs are the first hydrological storage compartments impacted by decreasing inflows from the contributing area. Droughts are especially critical for downstream reservoirs, which are more dependent on upstream river discharge and more affected by droughts.

\subsection{Other regions with significant lake/reservoir contribution}

Other regions of the world have been selected to examine the impact of lakes and surface water masses on GRACE 
(Table S1) and illustrate consequences expected from the synthetic experiment:

i. single lakes with significant mass variations (Guri Lake, Orinoco basin, $3900 \mathrm{~km}^{2}$, Fig. S4 and Tables S1, S3 and S4). In contrast to Lake Nasser, Guri Lake is located in a tropical climate with large natural seasonal storage fluctuations. The contribution of this single reservoir representing less than $1 \%$ of the basin area is significant, similar to the SMS contribution modeled by NOAH, and explains $25 \%(50 \mathrm{~mm})$ of seasonal variations in the lower Orinoco basin $\left(350000 \mathrm{~km}^{2}\right)$ and shifts the phase by 15 to 20 days (Table S3). This single lake explains nearly entirely the positive GRACE trend for the investigated period ( $20 \mathrm{~mm}_{\text {year }}{ }^{-1}, 7 \mathrm{~km}^{3} \mathrm{yr}$ ), while the NOAH model indicates a decreasing trend in SMS (Table S3). At the scale of the Orinoco basin as a whole $\left(1 \mathrm{M} \mathrm{km}^{2}\right)$, Guri Lake still contributes $\sim 10 \%$ to seasonal water storage variations, and $65 \%$ of the trend at the scale of the basin.

ii. A set of lakes (eastern African lakes, Fig. S5) illustrate lake contributions in eastern Africa (Xie et al., 2012). These eastern African lakes are interesting because while most of lakes are located at the edge or outside Tanzania $\left(1.2 \mathrm{M} \mathrm{km}^{2}\right)$, the interannual lake contribution is significant and reaches $80 \mathrm{~mm}$ in GRACE estimates (Fig. S5). Moreover, in the north Tanzanian coastal basin $\left(355000 \mathrm{~km}^{2}\right)$ located $300 \mathrm{~km}$ from the lakes, the predicted lake effect on GRACE differs for the two processing strategies (CSR and GRGS); they have different leakage signs in this region. This is confirmed when computing the difference between CSR and GRGS. After filtering the high-frequency noise, the long-term residuals show a clear correlation with Lake Victoria water level variations $(r=0.88)$. While Lake Victoria is more than $300 \mathrm{~km}$ from the outline of the north Tanzanian coastal basin, leakage from this lake still has a large amplitude and explains the differences between the two GRACE processing strategies.

\subsection{Surface Water Ocean Topography (SWOT) mission perspective}

Accurate GRACE estimates with substantial reservoir and/or lake storage changes will improve by incorporating a priori information regarding both location and amount of water masses into GRACE processing. Surface water has a large impact on TWS for large lakes with large volume variations (e.g., Lake Nasser, Guri Lake). A similar effect is expected in regions with large numbers of small lakes varying coherently (e.g., the Aral Sea region, the eastern African lakes, the Canadian Prairie, Yirdaw et al., 2008).

The value of supplementary information from satellite altimetry to monitor lake levels is evident, although limited by ground track spacing and fixed nadir pointing of recent and current missions. To improve sampling of surface water storage, Papa et al. (2010) proposed a multi-satellite product to monitor surface water extent at monthly timescales with $25 \mathrm{~km}$ spatial resolution, and construction of resulting hypsometry curves from lake level and area data to constrain lake volume variations (Cretaux et al., 2011).

In the coming decade several new satellite altimetry missions are planned that will provide long-term continuous time series of water levels over large lakes and reservoirs. New remote sensing imagery missions enabling land surface classification (including water extent) will also be launched. For example, several new satellites have been planned within the European Union framework of the Global Monitoring for Environment and Security (GMES). However, none of the missions will be dedicated to continental hydrology, in contrast to the Surface Water and Ocean Topography (SWOT) satellite, a joint NASA-CNES mission planned for a 2019 launch. It will be the first satellite designed to measure continental surface water. SWOT will provide a global inventory of all terrestrial water bodies whose surface area exceeds $250 \mathrm{~m}^{2}$ with sub-monthly sampling (Biancamaria et al., 2010). It should yield global sampling of many water bodies too small to be measured with current satellites. The principal SWOT instrument will be a Ka-band radar interferometer (KaRIN), which will provide heights and coregistered all weather imagery of water over 2 swaths, each $60 \mathrm{~km}$ wide, with an expected absolute height precision over lakes of $100 \mathrm{~mm} \mathrm{~km}^{-2}$. The potential of SWOT measurements will be enhanced when coupled with other remote sensing data, and the GRACE follow-on mission especially. SWOT should considerably improve our understanding of lakes and reservoirs water balance and their impact on continental total water storage.

\section{Conclusions}

We have investigated how spatial concentration and distribution of water masses affect GRACE water storage estimates. Reservoirs, lakes, glaciers, and small-scale groundwater systems with spatial scales well below GRACE nominal resolution act as point masses that significantly contribute to the GRACE signal when water storage variations are sufficiently large.

Two synthetic experiments illustrate a number of points relevant to interpreting GRACE estimates as basin-wide average water storage changes. Conclusions apply to any basin with irregular water storage distribution, whether due to human activity or not. The impact of the concentrated mass on water storage changes depends on the location and areal extent of the reservoirs, the basin area, and GRACE processing. The quantitative effect of water mass concentration on GRACE estimates is not obvious, especially for small basins. Forward modeling shows that if reservoir storage is assumed 
to be uniformly distributed, then the result may be an underestimation (when near the basin center) or overestimation (near the basin margin) by up to a factor of 2 . Consequently, the contribution of reservoir storage changes to GRACE storage changes is unlikely to be equal to a simple sum of reservoir storage variations. In addition, mass changes outside a basin of interest may contribute significantly because of leakage into the basin.

We have applied these results to several basins that contain significant anthropic reservoir management in the Middle East, and additional basins from different climate zones in the supplementary material. In the lower Nile basin, combining information on the position and extent of water bodies and water level variations from radar altimetry allows us to quantify the impact of reservoir storage on GRACE TWS estimates and to verify that large reservoirs contribute substantially to the hydrological cycle, at both seasonal and interannual timescales. For example, the area of Lake Nasser constitutes only $1.5 \%$ of the lower Nile basin area, but accounts for $\sim 95 \%$ of the seasonal water storage changes. As the lake is located near the basin margin, its impact on GRACE is half its volume variations.

In the Tigris-Euphrates basin, major reservoirs are located near the center of the basin; their impact on GRACE is larger than the simple sum of reservoir volume variations. Reservoir storage changes during the recent drought (October 2006September 2009) have been estimated $\sim 27 \mathrm{~km}^{3}$ from satellite altimetry. However, the computed impact on GRACE is twice as important $\left(45 \mathrm{~km}^{3}\right)$ and accounts for $\sim 50 \%$ of the TWS decline measured by GRACE. Assuming uniform reservoir storage distribution would have underestimated the reservoir contribution by $50 \%$, both soil moisture $(\sim 50 \%)$ and predicted impact of reservoir $(\sim 50 \%)$ account for most of the TWS decline of $93 \mathrm{~km}^{3}$ during the 2007 through 2009 drought. While large variability in SMS among LSMs precludes reliable estimation of trends in GWS depletion during the drought, it is expected to be very limited.

Inland lakes provide important sources of fresh water for agricultural and industrial uses globally, and are an important element in the hydrological budget. In dry regions in particular, agriculture relies heavily on surface water and dams are instruments of economic policy. With significant storage volumes and relatively short time response (compared to groundwater), lakes and reservoirs are important targets for monitoring by GRACE (e.g., Milzow et al., 2011; Velpuri et al., 2012). Because the influence of irregular water storage distribution is significant, GRACE estimates require careful interpretation in these cases, especially when attempting to separate changes in GWS in agricultural regions where both surface and groundwater are used conjunctively. The GRACE mission, supported by other satellite instruments, appears to be a useful observational tool in these semi-arid regions where water resources are scarce, irregularly distributed and ground-based programs to monitor water resources limited. It is also clear that GRACE estimates will be improved once it is possible to combine independent information on spatial distribution of water with GRACE observations, even when reservoir storage is not a major factor within a basin.

\section{Supplementary material related to this article is available online at http://www.hydrol-earth-syst-sci.net/ 17/4817/2013/hess-17-4817-2013-supplement.pdf.}

Acknowledgements. We used the Matlab computation suite "spherical harmonic transform and its inverse" by F. Simons, available on http://geoweb.princeton.edu/people/simons/software.html. This work has been supported by the National Aeronautics and Space Administration grant NNX08AJ84G. The authors acknowledge additional support from the Jackson School of Geosciences, Univ. of Texas at Austin. Authors thank D. Long for his help to prepare Fig. 4, A. Güntner and an anonymous reviewer for constructive comments.

Edited by: J. Liu

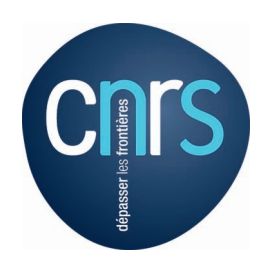

The publication of this article is financed by CNRS-INSU.

\section{References}

Abdelsalam, M., Youssef, A., Arafat, S., and Alfarhan, M.: Rise and demise of the New Lakes of Sahara, Geosphere, 4, 375-386, doi:10.1130/GES00142.1, 2008.

Abileah, R. and Vignudelli S.: A completely remote sensing approach to monitoring reservoirs water volume, International Water Technology Journal, 1, 59-72, 2011

Altinbilek, D.: The role of dams in development, Int. J. Water Resour. D., 18, 9-24, doi:10.1080/07900620220121620, 2002.

Alkama, R., Decharme, B., Douville, H., Becker, M., Cazenave, A., Sheffield, J., Voldoire, A., Tyteca, S., and Le Moigne, P.: Global Evaluation of the ISBA-TRIP Continental Hydrological System. Part I: Comparison to GRACE Terrestrial Water Storage Estimates and In Situ River Discharges, J. Hydrometeorol., 11, 583600, doi:10.1175/2010jhm1211.1, 2010.

Aly A., Froehlich K., Nada, A., Awad, M., Hamza, M., and Salem, W.: Study of Environmental Isotope Distribution in the AswanHigh- Dam Lake (Egypt) for Estimation of Evaporation of Lake Water and Its Recharge to Adjacent Groundwater, Environ. Geochem. Hlth., 15, 37-49, 1993.

Becker, M., LLovel, W., Cazenave, A., Guntner, A., and Cretaux, J.: Recent hydrological behavior of the East African great lakes region inferred from GRACE, satellite altimetry and rainfall observations, C. R. Geoscience, 342, 223-233, doi:10.1016/j.crte.2009.12.010, 2010. 
Bettadpur, S.: Level-2 Gravity Field Product User Handbook, The GRACE Project, Center for Space Research, University of Texas at Austin, 327-734, 2007.

Biancamaria, S., Andreadis, K., Durand, M., Clark, E., Rodriguez, E., Mognard, N., Alsdorf, D., Lettenmaier, D., and Oudin, Y.: Preliminary Characterization of SWOT Hydrology Error Budget and Global Capabilities, Ieee J. Sel. Top. Appl., 3, 6-19, doi:10.1109/JSTARS.2009.2034614, 2010.

Biswas, A. and Tortajada, C.: Development and large dams: A global perspective, Int. J. Water Resour. D., 17, 9-21, doi:10.1080/07900620120025024, 2001.

Boy, J. and Chao, B.: Time-variable gravity signal during the water impoundment of China's Three-Gorges Reservoir, Geophys. Res. Lett., 29, 2200, doi:10.1029/2002GL016457, 2002.

Bruinsma, S., Lemoine, J., Biancale, R., and Vales, N.: CNES/GRGS 10 day gravity field models (release 2) and their evaluation, Adv. Space Res., 45, 587-601, doi:10.1016/j.asr.2009.10.012, 2010.

Cretaux, J. F., Kouraev, A. V., Papa, F., Berge-Nguyen, M., Cazenave, A., Aladin, N., and Plotnikov, I. S.: Evolution of sea level of the big Aral Sea from satellite altimetry and its implications for water balance, J. Great Lakes Res., 31, 520-534, 2005.

Cretaux, J. F., Calmant, S., Romanovski, V., Shabunin, A., Lyard, F., Berge-Nguyen, M., Cazenave, A., Hernandez, F., and Perosanz, F.: An absolute calibration site for radar altimeters in the continental domain: Lake Issykkul in Central Asia, J. Geodesy, 83, 723-735, doi:10.1007/s00190-008-0289-7, 2009.

Cretaux, J. F., Jelinski, W., Calmant, S., Kouraev, A., Vuglinski, V., Berge-Nguyen, M., Gennero, M. C., Nino, F., Del Rio, R. A., Cazenave, A., and Maisongrande, P.: SOLS: A lake database to monitor in the Near Real Time water level and storage variations from remote sensing data, Adv. Space Res., 47, 1497-1507, doi:10.1016/j.asr.2011.01.004, 2011.

Döll, P., Kaspar, F., and Lehner, B.: A global hydrological model for deriving water availability indicators: model tuning and validation, J. Hydrol., 270, 105-134, doi:10.1016/S00221694(02)00283-4, 2003.

Döll, P., Hoffmann-Dobrev, H., Portmann, F.T., Siebert, S., Eicker, A., Rodell, M., Strassberg, G., and Scanlon, B.: Impact of water withdrawals from groundwater and surface water on continental water storage variations. J. Geodyn., 59, 143-156, doi:10.1016/j.jog.2011.05.001, 2012.

Easterling, D. R., Meehl, G. A., Parmesan, C., Changnon, S. A., Karl, T. R., and Mearns, L. O.: Climate extremes: Observations, modeling, and impacts, Science, 289, 2068-2074, doi:10.1126/science.289.5487.2068, 2000.

Feng, W., Zhong, M., Lemoine, J.-M., Biancale, R., Hsu, H.-T., and Xia, J.: Evaluation of groundwater depletion in North China using the Gravity Recovery and Climate Experiment (GRACE) data and ground-based measurements, Water Resour. Res., 49, 2110-2118, doi:10.1002/wrcr.20192, 2013.

Frappart, F., Papa, F., Guntner, A., Werth, S., da Silva, J. S., Tomasella, J., Seyler, F., Prigent, C., Rossow, W. B., Calmant, S., and Bonnet, M. P.: Satellite-based estimates of groundwater storage variations in large drainage basins with extensive floodplains, Remote Sens. Environ., 115, 1588-1594, doi:10.1016/j.rse.2011.02.003, 2011.

Frappart, F., Papa, F., da Silva, J. S., Ramillien, G., Prigent, C., Seyler, F., and Calmant, S.: Surface freshwater storage and dynamics in the Amazon basin during the 2005 exceptional drought, Environ. Res. Lett., 7, 044010, doi:10.1088/17489326/7/4/044010, 2012.

Gossel, W., Ebraheem, A., Sefelnasr, A. M., and Wycisk, P.: A GIS-based flow model for groundwater resources management in the development areas in the eastern Sahara, Africa. In: Applied Groundwater Studies in Africa. IAH Selected Papers on Hydrogeology, 13, 43-64, CRC Press/Balkema, Leiden, The Netherlands, 2008.

Güntner, A.: Improvement of Global Hydrological Models Using GRACE Data, Surv. Geophys., 29, 375-397, doi:10.1007/s10712-008-9038-y, 2008.

Hunger, M. and Döll, P.: Value of river discharge data for globalscale hydrological modeling, Hydrol. Earth Syst. Sci., 12, 841861, doi:10.5194/hess-12-841-2008, 2008.

Jongerden J.: Dams and Politics in Turkey: Utilizing Water, Developing Conflict, Middle East Policy Volume, 17, 137-143, doi:10.1111/j.1475-4967.2010.00432.x, 2010.

Jones, C., Sultan, M., Yan, E., Milewski, A., Hussein, M., Al-Dousari, A., Al-Kaisy, S., and Becker, R.: Hydrologic impacts of engineering projects on the Tigris-Euphrates system and its marshlands, J. Hydrol., 353, 59-75, doi:10.1016/j.jhydrol.2008.01.029, 2008.

Landerer, F. W. and Swenson, S. C.: Accuracy of scaled GRACE terrestrial water storage estimates, Water Resour. Res., 48, W04531, doi:10.1029/2011wr011453, 2012.

Lemoine, J.-M., Bruinsma, S., Loyer, S., Biancale, R., Marty, J.C., Perosanz, F., and Balmino, G.: Temporal gravity field models inferred from GRACE data, Adv. Space Res., 39, 1620-1629, doi:10.1016/j.asr.2007.03.062, 2007.

Liu, J. G. and Yang, H.: Spatially explicit assessment of global consumptive water uses in cropland: Green and blue water, J. Hydrol., 384, 187-197, doi:10.1016/j.jhydrol.2009.11.024, 2010.

Longuevergne, L., Scanlon, B. R., and Wilson, C. R.: GRACE Hydrological estimates for small basins: Evaluating processing approaches on the High Plains Aquifer, USA, Water Resour. Res., 46, W11517, doi:10.1029/2009wr008564, 2010.

Mutin, G.: L'eau dans le monde arabe. Mise à jour de la première édition. Paris, Ellipses Édition Marketing SA, 2000 ("Carrefours de Géographie ")., Études rurales, 155-156, http://arxiv.org/ftp/ arxiv/papers/0911/0911.4948.pdf, 2009.

Milzow, C., Krogh, P. E., and Bauer-Gottwein, P.: Combining satellite radar altimetry, SAR surface soil moisture and GRACE total storage changes for hydrological model calibration in a large poorly gauged catchment, Hydrol. Earth Syst. Sci., 15, 17291743, doi:10.5194/hess-15-1729-2011, 2011.

Oki T. and Sud Y. C.: Design of Total Runoff Integrating Pathways (TRIP) - A global river channel network. Earth Interactions, Available online: http://hydro.iis.u-tokyo.ac.jp/\$sim\$ $\$$ taikan/TRIPDATA/TRIPDATA.html, 2, 1998.

Papa, F., Prigent, C., Aires, F., Jimenez, C., Rossow, W. B., and Matthews, E.: Interannual variability of surface water extent at the global scale, 1993-2004, J. Geophys. Res.-Atmos., 115, D12111, doi:10.1029/2009jd012674, 2010.

Pokhrel, Y. N., Hanasaki, N., Yeh, P. J. F., Yamada, T. J., Kanae, S., and Oki, T.: Model estimates of sea-level change due to anthropogenic impacts on terrestrial water storage, Nat. Geosci., 5, 389-392, doi:10.1038/ngeo1476, 2012. 
Rodell, M., Houser, P. R., Jambor, U., Gottschalck, J., Mitchell, K., Meng, C. J., Arsenault, K., Cosgrove, B., Radakovich, J., Bosilovich, M., Entin, J. K., Walker, J. P., Lohmann, D., and Toll, D.: The global land data assimilation system, B. Am. Meteorol. Soc., 85, 381-394, doi:10.1175/bams-85-3-381, 2004.

Rodell, M., Velicogna, I., and Famiglietti, J. S.: Satellite-based estimates of groundwater depletion in India, Nature, 460, 999-980, doi:10.1038/nature08238, 2009.

Rowlands, D. D., Luthcke, S. B., McCarthy, J. J., Klosko, S. M., Chinn, D. S., Lemoine, F. G., Boy, J. P., and Sabaka, T. J.: Global mass flux solutions from GRACE: A comparison of parameter estimation strategies-Mass concentrations versus Stokes coefficients, J. Geophys. Res.-Sol. Earth, 115, B01403, doi:10.1029/2009jb006546, 2010.

Sadek, M. F., Shahin, M. M., and Stigter, C. J.: Evaporation from the reservoir of the High Aswan Dam, Egypt: A new comparison of relevant methods with limited data, Theor. Appl. Climatol., 56, 57-66, doi:10.1007/bf00863783, 1997.

Scanlon, B. R., Faunt, C. C., Longuevergne, L., Reedy, R. C., Alley, W. M., McGuire, V. L., and McMahon, P. B.: Groundwater depletion and sustainability of irrigation in the US High Plains and Central Valley, P. Natl. Acad. Sci. USA, 109, 9320-9325, doi:10.1073/pnas.1200311109, 2012a.

Scanlon, B. R., Longuevergne, L., and Long, D.: Ground referencing GRACE satellite estimates of groundwater storage changes in the California Central Valley, USA, Water Resour. Res., 48, W04520, doi:10.1029/2011wr011312, 2012b.

Schmidt, R., Flechtner, F., Meyer, U., Neumayer, K. H., Dahle, C., Konig, R., and Kusche, J.: Hydrological Signals Observed by the GRACE Satellites, Surv. Geophys., 29, 319-334, doi:10.1007/s10712-008-9033-3, 2008.

Shamsudduha, M., Taylor, R. G., and Longuevergne, L.: Monitoring groundwater storage changes in the highly seasonal humid tropics: Validation of GRACE measurements in the Bengal Basin, Water Resour. Res., 48, W02508, doi:10.1029/2011wr010993, 2012.

Siebert, S., Burke, J., Faures, J. M., Frenken, K., Hoogeveen, J., Döll, P., and Portmann, F. T.: Groundwater use for irrigation - a global inventory, Hydrol. Earth Syst. Sci., 14, 1863-1880, doi:10.5194/hess-14-1863-2010, 2010.

Singh, A., Seitz, F. and Schwatke, C.: Inter-annual water storage changes in the Aral Sea from multi-mission satellite altimetry, optical remote sensing, and GRACE satellite gravimetry, Remote Sens. Environ., 123, 187-195, 2012.

Simons, F. J., Dahlen, F. A., and Wieczorek, M. A.: Spatiospectral concentration on a sphere, Siam Review, 48, 504-536, doi:10.1137/s0036144504445765, 2006.

Sultan, M., Sturchio, N., Hassan, F. A., Hamdan, M. A. R., Mahmood, A. M., ElAlfy, Z., and Stein, T.: Precipitation source inferred from stable isotopic composition of Pleistocene groundwater and carbonate deposits in the Western Desert of Egypt, Quaternary Res., 48, 29-37, doi:10.1006/qres.1997.1907, 1997.

Swenson, S. and Wahr, J.: Post-processing removal of correlated errors in GRACE data, Geophys. Res. Lett., 33, L08402, doi:10.1029/2005g1025285, 2006.

Swenson, S. and Wahr, J.: Monitoring the water balance of Lake Victoria, East Africa, from space, J. Hydrol., 370, 163-176, doi:10.1016/j.jhydrol.2009.03.008, 2009.
Tapley, B. D., Bettadpur, S., Ries, J. C., Thompson, P. F., and Watkins, M. M.: GRACE measurements of mass variability in the Earth system, Science, 305, 503-505, doi:10.1126/science.1099192, 2004.

Tiwari, V. M., Wahr, J., and Swenson, S.: Dwindling groundwater resources in northern India, from satellite gravity observations, Geophys. Res. Lett., 36, L18401, doi:10.1029/2009g1039401, 2009.

Velpuri, N. M., Senay, G. B., and Asante, K. O.: A multi-source satellite data approach for modelling Lake Turkana water level: calibration and validation using satellite altimetry data, Hydrol. Earth Syst. Sci., 16, 1-18, doi:10.5194/hess-16-1-2012, 2012.

Vergnes, J.-P. and Decharme, B.: A simple groundwater scheme in the TRIP river routing model: global off-line evaluation against GRACE terrestrial water storage estimates and observed river discharges, Hydrol. Earth Syst. Sci., 16, 3889-3908, doi:10.5194/hess-16-3889-2012, 2012.

Voss, K. A., Famiglietti, J. S., Lo, M. H., de Linage, C., Rodell, M., and Swenson, S. C.: Groundwater depletion in the Middle East from GRACE with implications for transboundary water management in the Tigris-Euphrates-Western Iran region, Water Resour. Res., 49, 904-914, doi:10.1002/wrcr.20078, 2013.

Wada, Y., van Beek, L. P. H., van Kempen, C. M., Reckman, J., Vasak, S., and Bierkens, M. F. P.: Global depletion of groundwater resources, Geophys. Res. Lett., 37, L20402, doi:10.1029/2010g1044571, 2010.

Wahr, J., Molenaar, M., and Bryan, F.: Time variability of the Earth's gravity field: Hydrological and oceanic effects and their possible detection using GRACE, J. Geophys. Res.-Sol. Earth, 103, 30205-30229, doi:10.1029/98jb02844, 1998.

Wang, X. W., de Linage, C., Famiglietti, J., and Zender, C. S.: Gravity Recovery and Climate Experiment (GRACE) detection of water storage changes in the Three Gorges Reservoir of China and comparison with in situ measurements, Water Resour. Res., 47, W12502, doi:10.1029/2011wr010534, 2011.

Werth, S., and Guntner, A.: Calibration analysis for water storage variability of the global hydrological model WGHM, Hydrol. Earth Sys. Sc., 14, 59-78, 2010.

Xavier, L., Becker, M., Cazenave, A., Longuevergne, L., Llovel, W., and Rotunno, O. C.: Interannual variability in water storage over 2003-2008 in the Amazon Basin from GRACE space gravimetry, in situ river level and precipitation data, Remote Sens. Environ., 114, 1629-1637, doi:10.1016/j.rse.2010.02.005, 2010.

Xie, H., Longuevergne, L., Ringler, C., and Scanlon, B. R.: Calibration and evaluation of a semi-distributed watershed model of Sub-Saharan Africa using GRACE data, Hydrol. Earth Syst. Sci., 16, 3083-3099, doi:10.5194/hess-16-3083-2012, 2012.

Yirdaw, S. Z., Snelgrove, K. R., and Agboma, C. O.: GRACE satellite observations of terrestrial moisture changes for drought characterization in the Canadian Prairie, J. Hydrol., 356, 84-92, doi:10.1016/j.jhydrol.2008.04.004, 2008.

WCD: Dams and Development - A New Framework for Decision Making (London, Earthscan), 2000.

World Bank: The World's Experience with Large Dams: A Preliminary Review of Impacts (Washington, DC, World Bank), 1998. 